\title{
OPTIMISATION OF DISTRIBUTION ROUTES: A CASE STUDY
}

\author{
Rudolf Kampf, Martina Hlatká, Patrik Gross*
}

Department of Transport and Logistics, Faculty of Technology, Institute of Technology and Business in Ceske Budejovice, Ceske Budejovice, Czech Republic

*E-mail of corresponding author: gross@mail.vstecb.cz

\section{Resume}

This article focuses on optimisation of the distribution routes for a company that produces carpets, floor coverings and tapestries. The optimisation process is based on operational research methods including, without limitations, Mayer's method and the single linkage method. The obtained results are subsequently compared to the current situation and evaluated in terms of time and costs. The conclusion provides the optimised economic solution.

\section{Article info}

Received 13 July 2020

Accepted 21 July 2020

Online 12 November 2020

\section{Keywords:}

logistics,

transport,

transportation problem,

operational research,

Mayer's method,

single linkage method

ISSN 1335-4205 (print version)

ISSN 2585-7878 (online version)

\section{Introduction}

The modern age is characterised by the rapid technological progress, as facilitated by its creators, and the growing demands being placed on employees. On occasion, this combination of factors may lead to job losses within a company. However, if the adopted technologies fail to meet their potentials, there is a risk that the quality of products and services will fall, resulting in a significant loss of customers. In addition, the current supply of products and services hugely exceeds demand, which calls for greater appreciation of new and current buyers. Customer satisfaction and aftercare should, therefore, be the main objective of all the companies.

The company at the centre of this case study sells carpets, tapestries, floor coverings (PVC, vinyl, wood, laminate, linoleum, cork), mats, associated materials (underlay, glues, skirting boards, sanitizers and detergents), as well as offers related services, such as floor assembly, carpet laying and floor cleaning. The company's large number of customers means that the company must plan its distribution routes in detail. Long-standing customers (57 companies in South Bohemia) are extended free or reduced shipping costs. The company retains the option to compensate for these costs in the form of goods or services. Offering goods is considered risky due to the fierce competition on the market, so offering services is considered adequate compensation. Since retaining customer loyalty is not very easy nowadays, extra bonuses such as "free shipping" are a great enticement.

\section{Methodology}

The operational research focused on examining individual operations in terms of a set of scientific fields dealing with decision problems. In his book, Jablonsky refers to operational research as a scientific field - a set of relatively independent disciplines aimed at analysing different types of decision problems [1]. He further points out the impossibility of formulating an exact definition of operational research. However, he offers a rough outlining of what operational research covers by referring to the term as the research of operations. Within this context, other authors applied operational research to all the spheres dealing with analysis and coordination of performed operations (irrespective of their definition) within a system. For example, as a scientific tool for developing and supporting the solution of decision-making problems and the reduction of emergency situations in continuous transport with respect to the environment [1-3].

Operational analysis tries to achieve the highest possible quality of operations, or their mutual relationship, with a view to ensuring the smoothest possible functioning of a system. Setting specific criteria is vital for assessing the proper or unsuitable functioning of a system by means of mathematical modelling, which is an indispensable operational research tool. If one examines a transportation system based on the operational research, it is specifically this analysis that uses a model for that system [4-6]. 
Table 1 Design of an economic model for the transportation problem [1]

\begin{tabular}{|c|c|c|c|c|c|}
\hline \multirow{2}{*}{ sources } & sinks & \multicolumn{4}{|l|}{ source capacity } \\
\hline & $\mathrm{O}_{1}$ & $\mathrm{O}_{2}$ & $\cdots$ & $\mathrm{O}_{\mathrm{n}}$ & \\
\hline \multirow{2}{*}{$\mathrm{D}_{1}$} & $c_{11}$ & $\mathrm{c}_{12}$ & & $c_{1 \mathrm{n}}$ & \\
\hline & $\mathrm{x}_{11}$ & $\mathrm{x}_{12}$ & $\cdots$ & $\mathrm{x}_{1 \mathrm{n}}$ & $a_{1}$ \\
\hline \multirow{2}{*}{$\mathrm{D}_{2}$} & $\mathrm{c}_{21}$ & $\mathrm{c}_{22}$ & & $c_{2 n}$ & \\
\hline & $\mathrm{x}_{21}$ & $\mathbf{x}_{22}$ & $\cdots$ & $\mathrm{x}_{2 \mathrm{n}}$ & $\mathrm{a}_{2}$ \\
\hline . & . & . & $\cdot$ & . & . \\
\hline · & · & . & $\cdot$ & . & . \\
\hline . & . & . & . & . & . \\
\hline \multirow{2}{*}{$\mathrm{D}_{\mathrm{m}}$} & $\mathrm{c}_{\mathrm{m} 1}$ & $\mathrm{c}_{\mathrm{m} 2}$ & & $\mathrm{c}_{\mathrm{mn}}$ & \\
\hline & $\mathrm{x}_{\mathrm{m} 1}$ & $\mathrm{xm}_{2}$ & $\cdots$ & $\mathrm{x}_{\mathrm{mn}}$ & $\mathrm{a}_{\mathrm{m}}$ \\
\hline \multirow{2}{*}{ sinks' requirements } & & & & & $\sum_{\mathrm{i}} \mathrm{a}_{\mathrm{i}}$ \\
\hline & $\mathrm{b}_{1}$ & $\mathrm{~b}_{2}$ & $\ldots$ & $\mathrm{b}_{\mathrm{n}}$ & $\sum_{j} b_{j}$ \\
\hline
\end{tabular}

\section{The transportation problem}

Transportation problems generally are concerned with the scheduling distribution of specific goods or materials from supplier points (sources) to customers (sinks), with the intent to minimise the overall distribution costs [7].

Holoubek argues that transport tasks focus on delivering goods from supplier warehouses to customer storages by maximising the economics of the shipping process [8]. As one can see in Table 1, he points out that for each of $m$ supplier warehouses $D_{1}, D_{2} \ldots, D_{M}$ the maximum amount of $a_{1}, a_{2} \ldots, a_{m}$ to be delivered is defined. For each of $n$ customer storage facilities $O_{1}, O_{2} \ldots, O_{n}$ the maximum amount of $b_{1}, b_{2} \ldots, b_{n}$ to be stored is defined. Capacity and requirements are measured in identical and standard units of measure, i.e. tonne, pieces, etc. The last measured quantity is the transport intensity specifically referred to as shipping (transport) costs between the supplier warehouse $i$ and the customer storage facility $j$ designated as $c_{i j}$, where $i=1,2, \ldots, m$ and $j=1,2, \ldots n$ [8-10].

Resolving the transportation problem also includes case specific consideration for relationships between the total capacity of sources $\sum \mathrm{i} \mathrm{a}_{\mathrm{i}}$ (total of all the partial capacities) and all the requirements of the sinks $\Sigma j$ bj (total of all the requirements), whereby the formula is as follows:

$\sum i a_{i}=\sum j b_{j}$

For purposes of this problem, it will be referred to as the balanced transportation problem, i.e. one that satisfies all the requirements and fills all the capacities.

This transportation problem is calculated as follows:

$\sum i a_{i} \neq \sum j b_{j}$

For purposes of this problem will be referred to as the unbalanced transportation problem, i.e. one caused by the excess supply or demand, resulting in a waste of capacity (over capacity or shortage of).

\section{The travelling salesman problem}

Pelikan states that the travelling salesman assignments consist of looking for the optimal route for vehicles shipping goods using the travelling salesman technique, whereby distribution network nodes are served (supplied) once or more times, with the start and end of the route usually being the starting point. The key objective is to minimise the overall length of the route, while meeting customers' requirements and adhering to the technological restrictions imposed on the means of transport [11-12].

Other authors analysed the travelling salesman problem, thereby mostly focusing on the most economical way of delivering goods to customers. However, this is not concerned with the typical issue within the concept of the travelling salesman problem where customers are supplied from several points. In this case, goods delivery takes place along one route, starting and ending at the same point. Experts often call it a travelling salesman assignment. This task consists of getting from the starting point (point A1) and delivering goods to places A2, A3 ... A(n) at one time (in random order) and then returning to the starting point (A1). The route should be as short as possible with a view to finding the quickest route starting and ending at point A1 [13-15].

\section{Single and multiple travelling salesman problems}

Subrt defines a simpler single travelling salesman problem, which delivers goods along one route [16].

The mathematical model for the single travelling salesman problem is as follows:

$\min f=\sum_{i=1}^{m} \sum_{j=1}^{n} c_{i j} x_{i j}$

for which the following conditions apply:

$\begin{array}{ll}\sum_{i=1}^{n} x_{i j}=1 & \text { for } \mathrm{i}=1,2, \ldots, \mathrm{n}, \\ \sum_{i=1}^{n} x_{i j}=1 & \text { for } \mathrm{i}=1,2, \ldots, \mathrm{m},\end{array}$ 
$u_{i}-u_{j}+n x_{i j} \leq n-1 \quad$ for $\mathrm{i}=1,2, \ldots, \mathrm{m}$ and $\mathrm{j}=1,2$, $\ldots, \mathrm{n}$,

$$
x_{i j} \in\{0,1\} \quad \text { for } \mathrm{i}=1,2, \ldots, \mathrm{m} \text { and } \mathrm{j},=1,2, \ldots, \mathrm{n} \text {. }
$$

The first two conditions allow each node to be visited exactly once. The third condition ensures the indivisibility of the resulting Hamiltonian cycle, i.e. the graph cycle visits individual nodes only once, with the exception of the start node, which is also the end node [16-17].

\section{Mayer's method}

Ziskal and Havlicek argue that Mayer's method also focuses on scheduling routes by selecting minimal elements [18]. They further point to use of the multi-lane assignments with a complete route network and limited capacity. To solve the task based on the Mayer's method, it is necessary to use a symmetric matrix of distances. Inside the model, separate points form a sequence of distance points, whereby the central point is the last (e.g. a warehouse followed by other locations according to their distance). The matrix therefore indicates the farthest point and subsequently those points closer to the final destination - the central warehouse. According to the authors, Mayer's method consists of two steps [18].

The first step involves selection of points for individual routes, so that the first route includes the place farthest from the central position. Unless the vehicle exceeds its capacity, it goes on to the next point closest (shortest distance) to the previous location, followed by a check of the vehicle's capacity. Unless filled, the lorry, once again, goes to the next point closest (shortest distance) to the previous one, followed by a check of its capacity. The whole cycle repeats itself until the vehicle is packed to capacity. For scheduling of additional routes, the same method is applied.

The second step involves putting points on separate routes into order based on the intuitive decision-making and previous knowledge.

\section{$7 \quad$ Single linkage method}

In his publication, Subrt explains that this technique was developed from the distance matrix. The main principle is to determine the starting point and to subsequently find the most convenient connection (the shortest distance) to the next place. This point then serves for finding the closest nexus to a different point [15].

The calculation originated from the rate matrix (distances), with the starting point column, which is the last point, first being ruled out. The starting location line takes on a minimum-rate (distance) cell, which is integrated into the route and removes the designated column, followed by indication of the highest-rate cell in the column that corresponds to the specific location, complementing the route. The whole cycle repeats itself until all the points have been incorporated, whereby the route from the last points leads to the starting point (the central warehouse).

Paper explains that, one by one, all the points become starting points, each of them having an allocated route. In the event of an asymmetric rate matrix, the route must be traced in reverse. Such a situation will result in either the crossing out of lines and the detection of minimum rates in columns or in the whole procedure being conducted on a transposed matrix that results in an option for the most convenient route [19-20].

In her work, Frieblova states that the method in question involves considering each point as a starting point, i.e. picking the closest place from the starting location and subsequently the next closest point (unless already incorporated in the solution, which would mean selecting the second closest point) [21]. The cycle continues until the circuit closes, with the process repeated for all starting points. The so-called quasi-starting points, i.e. those places not identified as starting points, must be allocated with an accordingly adjusted route [21-22].

\section{Intuition method}

The intuition method always tackles simple and visible problems in the same way. This technique is highly economical.

Intuitively resolving problems embraces use of analogies, experience garnered from previous decisions and/or decisions taken on the basis of first impressions. These resolutions are often subliminal and are made to settle the petty problems [23].

\section{Analysis of current situation in the company}

The company at the centre of this case study sells carpets, tapestries, floor coverings (PVC, vinyl, wood, laminate, linoleum, cork), mats, associated materials (underlay, glues, skirting boards, sanitizers and detergents), as well as offers related services, such as floor assembly, carpet laying and floor cleaning.

Internal corporate data - customer address, order of unloading, time windows used for planning and meeting deadlines - provided the information necessary for the calculations. The goods register also contributed to scheduling of the distribution routes, which in turn provided information on kilometrage. All the obstacles on roads, for example bridges and other traffic safety restraints, were taken into consideration when working out the current shipping routes.

The company grants free shipping to long-term customers (57 companies in South Bohemia). The large number of customers means supply routes must be planned in detail. This article focuses particularly on the three delivery routes that are followed every week, namely:

- Monday- Jindrichuv Hradec, Pelhrimov, Tabor.

- Tuesday- Strakonice, Pisek, Klatov, Susice. 


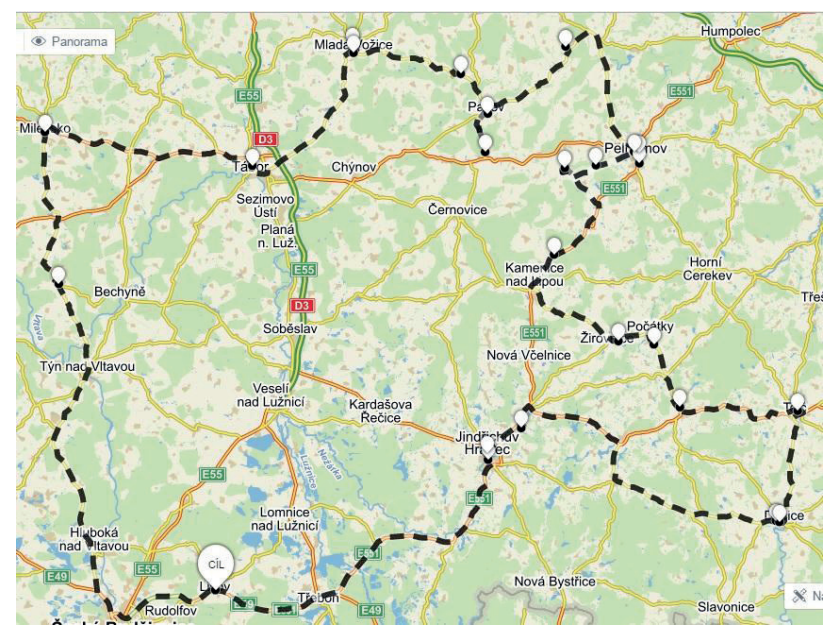

Figure 1 Route I [24]

- Wednesday - Kaplice, Cesky Krumlov, Prachatice, Vimperk, Ceske Budejovice.

If a public holiday falls on one of these days a different weekday is fixed.

An employee receives orders from individual customers and compiles a goods register (list and description of products). This is sent to the warehouse by fax. The warehouse workers gather the ordered goods, ordering and labelling pallets and/or boxes accordingly and in such way that the lorry can unload the goods as quickly as possible.

The following day, the driver unloads the ordered goods, making sure to unload the correct goods (incl. amount and quality) in the right place. To optimise the process, the following data were required:

- Vehicle loading capacity in kilograms

- Delivery addresses of customers

- Quantities (in kilograms) being unloaded for individual customers

- $\quad$ Time windows for unloading

- 3 routes run every week (the optimisation of which requires consideration being given to all the restrictions the driver must respect)

\section{Analysis of the company's organisational rules}

The company's organisational rules are as follows:

- Transport is provided using the company's lorry (capacity: 3.5 tonnes).

- Three different routes, with scheduled delivery to longterm customers each week (shipping goods regularly on Monday, Tuesday and Wednesday to 57 companies in South Bohemia).

- All the routes always begin and end in the town of Lisov.

- Only one driver at a time delivers goods.

- The driver is always accompanied by an assistant - a company employee who helps to unload the freight.

- The driver can choose from two alternatives with regards to work times:

- 6 a.m. start in Lisov and finishing no later than 5.30 p.m. in Lisov;
- flexible starting and finishing times according to customer requirements and the opening hours of unloading places.

- Time windows (e.g. 6.00 a.m. - 4.00 p.m.) shall be respected and goods delivered accordingly.

- The time required to complete the shipping route must not exceed the driver's maximum daily working hours.

- Drivers' breaks, as regulated by law, must be respected.

- Maximum weight limits (in relation to a specific distribution route and/or traffic restrictions) must be respected.

- Height, width and time restrictions imposed on lorries must be respected.

- $\quad$ Force majeure (congestions, drivers' incapacity, lorries' susceptibility to failure).

Microsoft Excel was used to carefully work out the three distribution routes with a view to effectively and efficiently process the collated data.

\section{Current distribution routes}

In this section, the routes are presented in terms of the exact number and sequence of unloading points on a particular day, kilometrage, average vehicle speed and the time spent on the route.

\subsection{Route I}

This route is followed on Mondays, involves 19 unloading points, with the town of Lisov being the loading point. The customer locations are as follows: Jindrichuv Hradec I - Jindrichuv Hradec II - Rodvinov - Dacice I Dacice II - Telc - Studena - Pocatky - Pelhrimov I - Pelhrimov II - Pelhrimov III - Pelhrimov IV - Arnestovice - Pacov I - Pacov II - Mlada Vozice I - Mlada Vozice II - Tabor Milevsko - Lisov. On Route I, which is $354 \mathrm{~km}$ long, it takes 175 minutes (i.e. 2:55 hrs) to unload freight weighing 3295 $\mathrm{kg}$. The net driving time is 6:65 hrs, excluding a 45-minute mandatory break. The total number of working hours 


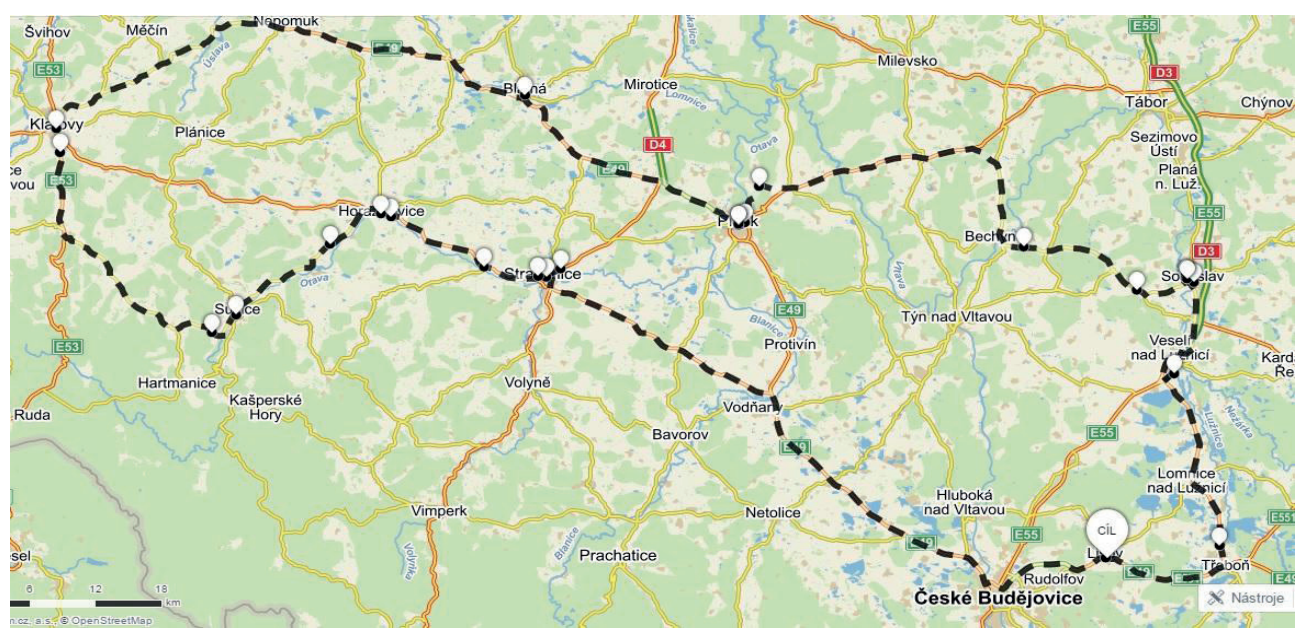

Figure 2 Route II [24]

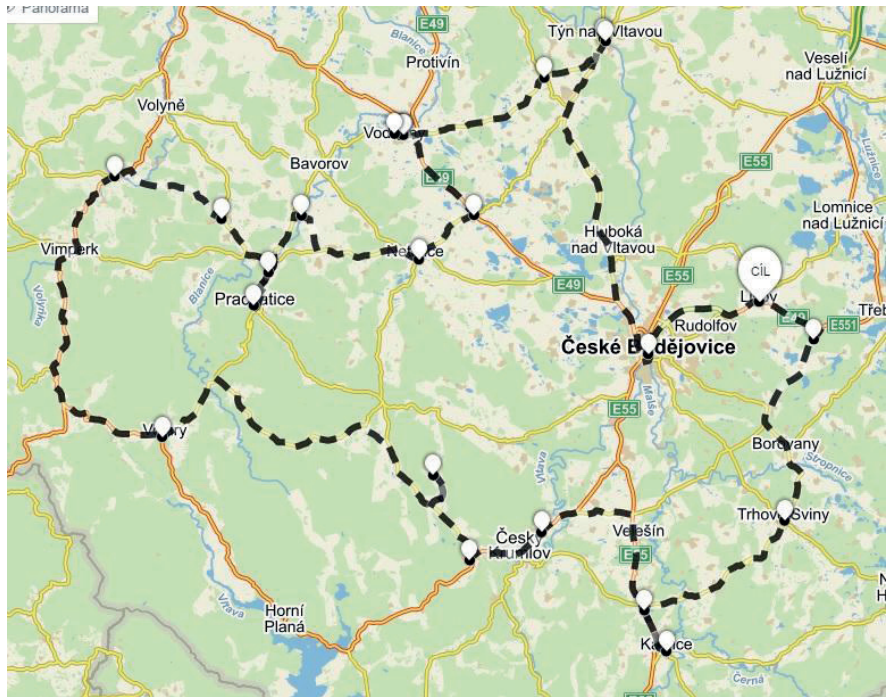

Figure 3 Route III [24]

Table 2 Overview of $\mathrm{km} /$ day in relation to driver's working hours

\begin{tabular}{cccc}
\hline shipping day & km/day & driver's working hours min/day & driver's working hours hrs/day \\
\hline Monday & 354 & 636 & $10: 36$ \\
Tuesday & 331 & 573 & $9: 33$ \\
Wednesday & 304 & 591 & $9: 51$ \\
total & $989 \mathrm{~km} / 3$ days & $1800 \mathrm{~min} / 3$ days & $30 \mathrm{hrs} / 3$ days \\
\hline
\end{tabular}

required to complete Monday's route is 10:36 hrs (636 minutes). Figure 1 illustrates the planned route that avoids all road restrictions.

\subsection{Route II}

This route is followed on Tuesdays, involves 20 unloading points, with the warehouse in the town of Lisov being the loading point. The customer locations are as follows: Veseli nad Luznici - Sobeslav I - Sobeslav II Sobeslav III - Vrcovice - Pisek I - Pisek II- Pisek III - Blatna - Klatovy I - Klatovy II - Susice - Susice Volsovy - Bojanovice - Horazdovice I - Horazdovice II - Katovice - Strakonice I Strakonice II - Strakonice III - Lisov. Total kilometrage is 331 $\mathrm{km}$ (average speed $55 \mathrm{~km} / \mathrm{h}$ ), total unloading time $165 \mathrm{~min}$, total cargo weight $3270 \mathrm{~kg}$, and net driving time 6:03 hrs, excluding a 45-minute mandatory break. The total number of working hours required to complete Tuesday's route is 9:33 hrs (573 minutes). Figure 2 shows Route II.

\subsection{Route No. III}

This route is followed on Wednesdays, involves 18 unloading points, with the warehouse in the town of Lisov being the loading point. The customer locations are as follows: Ceske Budejovice - Tyn nad Vltavou I - Tyn nad Vltavou II - Temelin - Vodnany I - Vodnany II - Vodnany III Netolice - Strunkovice nad Blanici - Prachatice - Vlachovo 
Table 3 Distance matrix

\begin{tabular}{|c|c|c|c|c|c|c|c|c|c|c|}
\hline & Lisov & J. Hradec I. & J. Hradec II. & Rodvinov & Dacice I. & Dacice II. & Telc & Studena & Pocatky & $\ldots$ \\
\hline Lisov & 0 & 40.7 & 41.2 & 48.1 & 95.6 & 94.9 & 82.6 & 69.1 & 62.4 & $\ldots$ \\
\hline J. Hradec I. & 40.7 & 0 & 1.5 & 7.2 & 34.2 & 34.1 & 41.8 & 28.3 & 21.5 & $\ldots$ \\
\hline $\begin{array}{l}\text { J. Hradec } \\
\text { II. }\end{array}$ & 41.2 & 1.5 & 0 & 5.6 & 36 & 35.8 & 40.2 & 26.7 & 19.9 & $\ldots$ \\
\hline Rodvinov & 48.1 & 7.2 & 5.6 & 0 & 38.2 & 38.1 & 36.6 & 23.1 & 16.4 & $\ldots$ \\
\hline Dacice I. & 95.6 & 34.2 & 36 & 38.2 & 0 & 0.55 & 15.3 & 20.1 & 38.3 & $\ldots$ \\
\hline Dacice II. & 94.9 & 34.1 & 35.8 & 38.1 & 0.55 & 0 & 15.1 & 19.9 & 38.6 & $\ldots$ \\
\hline Telc & 82.6 & 41.8 & 40.2 & 36.6 & 15.3 & 15.1 & 0 & 14.8 & 25.5 & $\ldots$ \\
\hline Studena & 69.1 & 28.3 & 26.7 & 23.1 & 20.1 & 19.9 & 14.8 & 0 & 11.1 & $\ldots$ \\
\hline Pocatky & 62.4 & 21.5 & 19.9 & 16.4 & 38.8 & 38.6 & 25.5 & 11.1 & 0 & $\ldots$ \\
\hline
\end{tabular}

Brezi - Ckyne - Volary - Borova - Kajov - Prisecna - Kaplice - Trhove Sviny - Lisov. Total kilometrage is $304 \mathrm{~km}$ (average vehicle speed $51 \mathrm{~km} / \mathrm{h}$ ), total unloading time 185 minutes, total cargo weight $3460 \mathrm{~kg}$, and net driving time 6:01 hrs, excluding a 45-minute mandatory break. The total number of working hours required to complete Wednesday's route is 9:51 hrs (591 minutes). Figure 3 shows Route III.

\section{Calculation of overall transport costs}

The overall transport costs provide an essential indicator of the impact thereof on the company's profits. The lorry's average fuel consumption is $18 \mathrm{l} / 100 \mathrm{~km}$. Although diesel prices fluctuate, a price of $1.30 \mathrm{EUR} / \mathrm{l}$ is used for the price calculation per $\mathrm{km}$, which is as follows:

Calculation of costs of diesel $/ \mathrm{km}$ : $0.18^{*} 1.3=0.234 \mathrm{EUR}$

Driver costs are $0.56 \mathrm{EUR} / \mathrm{km}$ with daily remuneration of 36 EUR per day. The difference between the price of diesel per kilometre and the price charged by the shipper per kilometre is $0.33 \mathrm{EUR}$ (0.56 EUR $-0.22 \mathrm{EUR}=0.33$ EUR), with the calculated amount being used for vehicle amortization, regular maintenance, road tax, extraordinary events and the driver's remuneration [25].

Table 2 presents the overall transport costs of the company in terms of the total kilometrage per week and total working hours for each day. The costs for Monday, Tuesday and Wednesday are 198.24 EUR, 185.36 EUR, and 170.24 EUR, respectively. This brings total weekly costs to 553.84 EUR + 108 EUR (total remuneration for driver for 3 days) $=661.84$ EUR. On a monthly basis, this is equivalent to 2647.36 EUR, and on an annual basis 31768.32 EUR.

\section{Optimisation of distribution routes}

To optimise the distribution routes of the company, it is necessary to draw up a distance matrix of the individual customer points. The distance matrix must be symmetric, containing 57 lines (customers) and the loading place (warehouse in Lisov), i.e. 58 x 58. Because of its massive size, Table 3 represents only a part of the designed matrix.

The matrix explores the kilometrage within each combination of analysed customer points, which is of critical importance for making final decisions. The model is symmetric, i.e. the kilometrage from point A to point B and vice versa is the same. MSExcel was used to draw up the list of customer points, and googlemaps.com and mapy.cz for compiling the whole pattern.

\section{Application of the Mayer's method}

The Mayer's method is an important tool with which to determine routes to the closest destinations and for their subsequent integration into a single route. The Mayer's method involves searching for and including individual customer points into the specific circuits. The basis for the application of the method was 58 locations (including the distribution warehouse in Lisov) divided over the three distribution routes and hired drivers for three days a week, with a focus on bringing down the driver costs to 0.56 EUR/ $\mathrm{km}$. The task is to optimise these three routes, thereby reducing the total kilometrage, whilst meeting the following requirements:

- Cargo weight must not exceed 3.5 tonnes;

- Time windows for deliveries must be adhered to;

- Driver's daily working hours must not exceed the prescribed limit; if the driving time exceeds $4.5 \mathrm{hrs}$, the driver is entitled to a 45-minute break, which is to be included in the total working hours.

\subsection{Route I}

The first step is, with help of the distance matrix, to determine the farthest place from the distribution warehouse in Lisov, which is the customer point identified as Klatovy I. At a distance of $116 \mathrm{~km}$ from the distribution warehouse, Klatovy I is therefore the first point on the 
Table 4 Application of the Mayer's method to Route I

\begin{tabular}{|c|c|c|c|}
\hline customer place & unloading time (min) & goods weight (kg) & time windows \\
\hline Klatovy I. & 5 & 60 & 6 a.m.-6 p.m. \\
\hline Klatovy II. & 10 & 100 & 8 a.m.-5 p.m. \\
\hline Susice & 10 & 120 & 8 a.m.-5 p.m. \\
\hline Susice-Volsovy & 10 & 100 & 8 a.m.-5 p.m. \\
\hline Horazdovice II. & 5 & 80 & 8 a.m.-5 p.m. \\
\hline Bojanovice & 10 & 90 & 6 a.m.-5 p.m. \\
\hline Horazdovice I. & 5 & 90 & 8 a.m.-5 p.m. \\
\hline Katovice & 20 & 900 & 6 a.m.-5 p.m. \\
\hline Strakonice III. & 10 & 140 & 7 a.m.-5 p.m. \\
\hline Strakonice II. & 5 & 50 & 6 a.m.-6 p.m. \\
\hline Blatna & 5 & 50 & 6 a.m.-6 p.m. \\
\hline Strakonice I. & 10 & 130 & 6 a.m.-6 p.m. \\
\hline Pisek III. & 5 & 70 & 8 a.m.-5 p.m. \\
\hline Pisek II. & 20 & 650 & 8 a.m.-5 p.m. \\
\hline Pisek I. & 5 & 90 & 6 a.m.-6 p.m. \\
\hline Vodnany III. & 10 & 120 & 8 a.m.-5 p.m. \\
\hline Vrcovice & 5 & 80 & 6 a.m.-6 p.m. \\
\hline Vodnany I. & 5 & 100 & 8 a.m.-5 p.m. \\
\hline Vodnany II. & 10 & 80 & 8 a.m.-5 p.m. \\
\hline Milevsko & 10 & 100 & 6 a.m.-6 p.m. \\
\hline Temelin & 10 & 110 & 6 a.m.-6 p.m. \\
\hline Tyn nad Vlt. I. & 10 & 120 & 6 a.m.-6 p.m. \\
\hline Tyn nad Vlt. II. & 5 & 50 & 6 a.m.-6 p.m. \\
\hline total & 200 Min & $3.480 \mathrm{Kg}$ & \\
\hline
\end{tabular}

designated route. From Klatovy I, the distance model identifies the closest customer point from this town, which is Klatovy II $2.3 \mathrm{~km}$ away. The choice of customer point must take into consideration the capacity of the lorry. The total weight of the cargo is $160 \mathrm{~kg}$ (Klatovy I $60 \mathrm{~kg}$; Klatovy II $100 \mathrm{~kg}$ ), therefore within capacity. It is now necessary to cross out the already visited places in the distance matrix so as to prevent repeat visits to these points. After crossing out the lines and columns for Klatovy I and II, the next stop is Susice (total weight of goods $120 \mathrm{~kg}$ ). This cycle repeats itself until the capacity of the lorry has been filled and/or the 23 customer points have been visited. Table 4 shows the suggested shipping route.

\subsection{Route No. II}

The second farthest place (not included in Route I) is Arnestovice some $98 \mathrm{~km}$ from the distribution warehouse in Lisov. It is now necessary to identify other customer points closest to Arnestovice, but which have not yet been crossed out in the distance matrix and whilst making sure that each customer point is visited only once. The procedure for this is the same as described for Route I. The total weight of the cargo on Route II is $3465 \mathrm{~kg}$ with an unloading time of 190 minutes.

\subsection{Route III}

The farthest customer point is Volary, $70.8 \mathrm{~km}$ from the distribution warehouse in Lisov. Route III only includes 12 customer points: Volary, Prachatice, Vlachovo Brezi, Strunkovice, Ckyne, Netolice, Ceske Budejovice, Prisecna, Trhove Sviny, Kajov, Borova and Kaplice. The total weight of the cargo is $3070 \mathrm{~kg}$ with an unloading time of 140 minutes.

\section{Single linkage method}

After dividing the customer points over the three routes, through application of the Mayer's method, it is necessary to arrange the customer points by distance in the shortest possible order. The single linkage method involves considering each customer point as a starting point, with the next closest point being identified as the follow-up 
Table 5 Single linkage method - Route I

\begin{tabular}{|c|c|}
\hline route I & distance \\
\hline $\begin{array}{l}\text { Lisov - Strakonice I - Strakonice II - Strakonice III - Katovice - Horazdovice II - Horazdovice I - Bojanovice - } \\
\text { Susice - Susice Volsovy - Klatovy II - Klatovy I - Blatna - Pisek III - Pisek II - Pisek I - Vrcovice - Milevsko - Tyn } \\
\text { nad Vltavou I - Tyn nad Vltavou II - Temelin - Vodnany I - Vodnany II - Vodnany III - Lisov }\end{array}$ & $346.8 \mathrm{~km}$ \\
\hline \multicolumn{2}{|l|}{ Table 6 Single linkage method - Route II } \\
\hline route II & distance \\
\hline $\begin{array}{l}\text { Lisov - Veseli nad Luznici - Sobeslav I - Sobeslav II - Sobeslav III - Tabor - Mlada Vozice II - Mlada Vozice I - } \\
\text { Pacov I - Pacov II - Arnestovice - Pelhrimov III - Pelhrimov II - Pelhrimov IV - Pelhrimov I - Pocatky - Studena } \\
\text { - Telc - Dacice II - Dacice I - Jindrichuv Hradec I - Jindrichuv Hradec II - Rodvinov - Lisov }\end{array}$ & $330.15 \mathrm{~km}$ \\
\hline \multicolumn{2}{|l|}{ Table 7 Single linkage method - Route III } \\
\hline route III & distance \\
\hline $\begin{array}{l}\text { Lisov - Ceske Budejovice - Trhove Sviny - Kaplice - Prisecna - Kajov - Borova - Netolice - Strunkovice - } \\
\text { Vlachovo Brezi - Prachatice - Volary - Ckyne - Lisov }\end{array}$ & $279.9 \mathrm{~km}$ \\
\hline
\end{tabular}

destination (if it is already included in the solution, the second closest customer point is found). This cycle repeats itself until the circuit is closed. The same procedure applies to all the starting points, with exception of the quasistarting points, which requires suitable modification of the route [26-27].

\subsection{Order of customer points on Route I}

The order of customer points on Route I, according to the single linkage method, starts in Lisov, goes to Strakonice I and ends in Lisov. The total distance is 346.8 $\mathrm{km}$. Table 5 shows the shortest route.

Based on that, the total time required to cover the route is calculated and compared to the driver's working hours. The overall unloading time is 200 minutes, net driving time $6: 31 \mathrm{hrs}$, average speed $53 \mathrm{~km} / \mathrm{h}$, whilst making sure not to exceed the prescribed 9 hours (after $4.5 \mathrm{hrs}$ the driver is obliged to take a 45 -minute break) or 10 hours (if the route takes longer than 9 hours, the driver is entitled to a second break of 45 minutes). The total working time amounts to 636 minutes (10:36 hrs) including the mandatory break of 45 minutes. If the driver starts at 5.55 a.m., he should be back in Lisov no later than 4.45 p.m.

\subsection{Order of customer points on Route II}

The order of customer points on Route II, according to the single linkage method, starts in Lisov, goes to Veseli nad Luznici and ends in Lisov. The total distance is $330.15 \mathrm{~km}$. Table 6 below shows the shortest route.

As before, the total time required to cover the route is calculated and compared to the driver's working hours. The overall unloading time is 190 minutes, net driving time 6:37 hrs, average speed $52 \mathrm{~km} / \mathrm{h}$. The total route time amounts to $587 \mathrm{~min}+45 \mathrm{~min}$ (mandatory driver's pause). The total working time, including the obligatory break, is 632 minutes.
If the driver starts at 5.25 a.m., he should therefore be back in Lisov by 3.57 p.m.

\subsection{Order of customer points on Route III}

The order of customer points on Route III, according to the single linkage method, starts in Lisov, with the first customer point being in Ceske Budejovice. The total distance is $279.9 \mathrm{~km}$. Table 7 shows the shortest route.

If the driver drives at an average speed of $54 \mathrm{~km} / \mathrm{h}$, the net driving time is 5:23 hrs, which, with an unloading time of 140 minutes, plus a 45-minute mandatory break, comes to a total of 508 minutes (8:28 hrs). If the driver starts work at 6.40 a.m., this would mean that he would return to Lisov 3.08 p.m.

\section{Application of the intuition method}

Experimental findings suggest this method produces the best results (lowest kilometrage). The internet application mapy.cz processed the factual data on addresses of the customers, which were placed in the most convenient order.

\subsection{Order of customer points on Route I}

The distance of Route I could be cut to $330.2 \mathrm{~km}$. The total time this would take is $6: 15 \mathrm{hrs}$ (at an average speed of $53 \mathrm{~km} / \mathrm{h}$ ). The driver's number of working hours $=6: 15 \mathrm{hrs}$ + 45 minutes (compulsory break) +200 minutes (unloading time $)=620 \mathrm{~min}(10: 20 \mathrm{hrs})$.

\subsection{Order of customer points on Route II}

Applying the intuition method to Route II produces the three significant changes (for Jindrichuv Hradec I, Jindrichuv Hradec II and Rodvinov), with the rest of the 
Table 8 Comparison of methods - Route I

\begin{tabular}{ll}
\hline method & route I \\
\hline \multirow{2}{*}{$\begin{array}{l}\text { single linkage } \\
\text { method }\end{array}$} & Lisov - Strakonice I - Strakonice II - Strakonice III - Katovice - Horazdovice II - Horazdovice I - \\
& I - Vrcovice - Milevsko - Tyn nad Vltavou I - Tyn nad Vltavou II - Temelin - Vodnany I - Vodnany \\
& II - Vodnany III - Lisov \\
& Lisov - Temelin - Tyn nad Vltavou I - Tyn nad Vltavou II - Milevsko - Vrcovice - Pisek III - Pisek \\
intuition & II - Pisek I - Blatna - Klatovy I - Klatovy II - Susice Volsovy - Susice - Bojanovice - Horazdovice II \\
method & - Horazdovice I - Katovice - Strakonice III - Strakonice II - Strakonice I - Vodnany III - Vodnany \\
& II - Vodnany I - Lisov \\
\hline
\end{tabular}

Table 9 Comparison of methods - Route II

\begin{tabular}{ll}
\hline method & route II \\
\hline \multirow{2}{*}{$\begin{array}{l}\text { single linkage } \\
\text { method }\end{array}$} & I - Pacov I - Pacov II - Pelhrimov I - Pelhrimov IV - Pelhrimov II - Pelhrimov III - Arnestovice \\
& - Pocatky - Studena - Telc - Dacice II - Dacice I - Jindrichuv Hradec I - Jindrichuv Hradec II - \\
& Rodvinov - Lisov \\
& Lisov - Veseli - Sobeslav I - Sobeslav II - Sobeslav III - Tabor - Mlada Vozice II - Mlada Vozice \\
intuition & I - Pacov I - Pacov II - Pelhrimov I - Pelhrimov IV - Pelhrimov II - Pelhrimov III - Arnestovice \\
method & - Pocatky - Studena - Telc - Dacice II - Dacice I - Rodvinov - Jindrichuv Hradec I - Jindrichuv \\
\hline & Hradec II - Lisov \\
\hline
\end{tabular}

Table 10 Comparison of methods - Route III

\begin{tabular}{|c|c|c|}
\hline method & route III & distance \\
\hline $\begin{array}{l}\text { single linkage } \\
\text { method }\end{array}$ & $\begin{array}{l}\text { Lisov - Ceske Budejovice - Trhove Sviny - Kaplice - Prisecna - Kajov - Borova - Netolice - } \\
\text { Strunkovice - Vlachovo Brezi - Prachatice - Volary - Ckyne - Lisov }\end{array}$ & $279.9 \mathrm{~km}$ \\
\hline $\begin{array}{l}\text { intuition } \\
\text { method }\end{array}$ & $\begin{array}{l}\text { Lisov - Trhove Sviny - Kaplice - Prisecna - Kajov - Borova - Volary - Ckyne - Vlachovo Brezi - } \\
\text { Prachatice - Strunkovice nad Blanici - Netolice - Ceske Budejovice - Lisov. }\end{array}$ & $268.4 \mathrm{~km}$ \\
\hline
\end{tabular}

route being identical to that of the best solution of the single linkage method. The distance is $326.75 \mathrm{~km}$, and the net driving time $6: 18 \mathrm{hrs}$ at an average speed of $52 \mathrm{~km} / \mathrm{h}$. In this case, the driver's number of working hours $=6: 18 \mathrm{hrs}$ + 45 minutes (compulsory break) +190 minutes (unloading time $)=613$ minutes $(10: 13 \mathrm{hrs})$.

\subsection{Order of customer points on Route III}

Under the intuition method, the distance of Route III dropped to $268.4 \mathrm{~km}$. The net driving time is 5:05 hrs at an average speed of $53 \mathrm{~km} / \mathrm{h}$. In this case, the driver's number of working hours $=5: 05 \mathrm{hrs}+45$ minutes (compulsory break) +140 minutes (unloading time $)=490$ minutes $(8: 10$ hrs).

\section{Evaluation of the optimised routes - Comparison of the single linkage method and intuition method}

\subsection{Route I - Monday}

The shortest route identified by the single linkage method produced worse results than that devised by the intuition method. The reason for this is that the single linkage method line does not reflect the closest and most suitable place. This omission may result in a customer point being ruled out because it is situated in an unfavourable location on the route. Table 8 shows results of application of both methods.

\subsection{Route II - Tuesday}

In this case, the shortest route identified by the single linkage method also produces the worse result than that devised by the intuition method, but only by a margin of $3.4 \mathrm{~km}$. The difference lies in the single linkage method's approach to the closest possible place, which excludes the most convenient way. For example, the journey from Dacice I to Jindrichuv Hradec I is the shortest, yet not the handiest route. A more suitable route would be for the driver to first go to Rodvinov and then to Jindrichuv Hradec, saving $3.4 \mathrm{~km}$. Table 9 shows results of application of both methods.

\subsection{Route III - Wednesday}

Table 10 shows results of application of both methods to Route III. Once again, the intuition method produces the best results. On this route, the driver would therefore unload in Trhove Sviny first. 
Table 11 Comparison of driver's working hours

\begin{tabular}{lccc}
\hline routes & current situation (hours) & single linkage method (hours) & intuition method (hours) \\
\hline route I - Monday & $10: 36$ & $10: 36$ & $10: 20$ \\
route II - Tuesday & $9: 33$ & $10: 32$ & $10: 13$ \\
route III - Wednesday & $9: 51$ & $8: 28$ & $8: 10$ \\
total working hours & 30 & $29: 36$ & $28: 43$ \\
\hline
\end{tabular}

\section{Calculation of annual costs}

The company currently pays annual transport costs of 31768.32 EUR. Under the single linkage approach, this would be 30904.32 EUR, leading to annual savings of 864 EUR. However, under the intuition method, this would fall even further still to 30057.60 EUR, thereby generating annual savings of 1710.72 EUR.

Current situation: $\quad 2647.36 * 12=31768.32$ EUR Single linkage method: $\quad 2575.36 * 12=30904.32$ EUR Intuition method: $\quad 2504.80 * 12=30057.60$ EUR

In percentage terms, the annual savings under the single linkage method would be $2.72 \%$, whilst under the intuition method 5.39\%.

\section{Calculation of time savings}

Evaluating the time savings is another variable that requires consideration. Table 11 compares the driver's current number of working hours for each route (in total $30 \mathrm{hrs}$ over 3 days) to that under the single linkage method (29:36 hours over 3 days) and the intuition method (28:43 hours over 3 days).

\section{Conclusion}

Firstly, the specific terms used in the article, were defined like the operational research, transportation problem, travelling salesman problem and multiple travelling salesman problems.

An analysis of the company's current situation pointed us towards resolving the multiple travelling salesman problem using the Mayer's method. The very first step was to design a symmetric distance matrix (58 x 58 towns/ customer points). The second step consisted of dividing the customer points over three routes with symmetric matrices ( $24 \times 24 ; 23 \times 23$; and $13 \times 13$ ). The applied methodology connected individual customer points, without thinking about appropriateness of the order in which they were visited. The third stage saw towns and cities (customer points) arranged within the travelling salesman problem through application of the two methods, namely the single linkage method and the intuition method.

The single linkage method helped to put the specific customer points in a particular order, thereby producing the lowest kilometrage. The total distance under this method came to $956.85 \mathrm{~km}$. However, the intuition method produced the lower result, namely a distance of $925.35 \mathrm{~km}$. Both methods provided the shortest routes for the relevant shipping days, whilst maintaining the driver's schedule according to the given time windows.

Overall, the intuition method produced the better results. The main reason for this is that in practice, full integration of the shortest distance does not always produce the most suitable route.

The final part of the work focused on a detailed comparison of the original overall annual transport costs (31768.32 EUR) with those under the single linkage method (30904.32 EUR; savings of 2.72\%) and the intuition method (30057.60 EUR; savings of 5.34\%). Evaluation of these approaches also enabled a comparison to be made of the driver's working hours on each route and in total according to the two methods applied. Under the current situation this is $30 \mathrm{hrs}$ over 3 days, under the single linkage method 29:36 hrs over 3 days and under the intuition method 28:43 hrs over 3 days.

In conclusion, the optimisation process under the intuition method was found to generate savings of 1710.72 EUR, which is a valuable contribution to the company's economic results.

\section{References}

[1] JABLONSKY, J. Operational research (in Czech). 2. ed. Prague: Vysoka skola ekonomicka, 1999. ISBN 80-7079-597-2.

[2] JOVCIC, S., PRUSA, P., DOBRODOLAC, M., SVADLENKA, L. A Proposal for a decision-making tool in third-party logistics (3PL) provider selection based on multi-criteria analysis and the fuzzy approach. Sustainability [online]. 2019, 11(15), 4236. eISSN 2071-1050. Available from: https://doi.org/10.3390/su11154236

[3] STROHMANDL, J., CEMPIREK, M. Experimental measurements used to reduce emergency situations of environmental continuous transport. In: 20th International Scientific Conference Transport Means 2016: proceedings. Kaunas University of Technology, 2016. p. 835-839. FABIANOVA, J., KACMARY, P., JANEKOVA, J. Operative production planning utilising quantitative forecasting and Monte Carlo simulations. Open Engineering [online]. 2019, 9(1), p. 613-622. eISSN 2391-5439. Available from: https://doi.org/10.1515/eng-2019-0071 
[4] STOPKA, O., JERABEK, K., STOPKOVA, M. Using the operations research methods to address distribution tasks at a city logistics scale. Transportation Research Procedia [online]. 2020, 44, 348-355. ISSN 2352-1465. Available from: https://doi.org/10.1016/j.trpro.2020.02.032

[5] VIEIRA, C. L. S., LUNA, M. M. M. Models and methods for logistics hub location: a review towards transportation networks design. Pesquisa Operacional [online]. 2016, 36(2), p. 375-397. ISSN 0101-7438, eISSN 1678-5142. Available from: https://doi.org/10.1590/0101-7438.2016.036.02.0375

[6] FEDORKO, G, MOLNAR, V., HONUS, S., NERADILOVA, H., KAMPF, R. The application of simulation model of a milk run to identify the occurrence of failures. International Journal of Simulation Modelling [online]. 2018, 17(3), p. 444-457. ISSN 1726-4529. Available from: https://doi.org/10.2507//jsimm17(3)440

[7] MAIOROV, N., FETISOV, V., KRILE, S., MISKOVIC, D. Simulation of the route network and ferry traffic intensity based on the process of discretization and circos plot intensity diagram. Transport Problems. 2019, 14(4), p. 23-30. ISSN 1896-0596, eISSN 2300-861X. Available from: https://doi.org/10.20858/tp.2019.14.4.2

[8] HOLOUBEK, J. Economic and mathematical methods (in Czech). 2. ed. Brno: Mendel University in Brno, 2010. ISBN 978-80-7375-411-2.

[9] CEJKA, J., BARTUSKA, L., TURINSKA, L. Possibilities of using transport terminals in South Bohemian region. Open Engineering [online]. 2017, 7(1), p. 55-59. eISSN 2391-5439. Available from: https://doi.org/10.1515/eng-2017-0010

[10] KUBASAKOVA, I., KUBANOVA, J. The usage of simulation road transport for company operating on the market. In: International Conference Transport Means 2019: proceedings. 2019.

[11] PELIKAN, J. Practicum in operational research (in Czech). Prague: University of Economics, 1993. ISBN 80-7079-135-7.

[12] GEORGIJEVIC, M., BOJIC, S., BRCANOV, D. The location of public logistic centers: an expanded capacity-limited fixed cost location-allocation modeling approach. Transportation Planning and Technology [online]. 2013, 36(2), p. 218-229. ISSN 0308-1060, eISSN 1029-0354. Available from: https://doi.org/10.1080/03081060.2013.770945

[13] MATTEO, U. D., PEZZIMENTI, P. M., ASTIASO GARCIA, D. Methodological proposal for optimal location of emergency operation centers through multi-criteria approach. Sustainability. 2016, 8(1), 50. eISSN 2071-1050. Available from: https://doi.org/10.3390/su8010050

[14] TOMKOVA, E., MIKUSOVA, N. Application of the competitiveness model in city Poprad. In: Economic and Management Forum PEMF 2019: proceedings. Ruzomberok: Verbum - Catholic University in Ruzomberok Press, 2019. ISBN 978-80-561-0671-6, p. 332-342.

[15] FEDORKO, G., HEINZ, D., MOLNAR, V., BRENNER, T. Use of mathematical models and computer software for analysis of traffic noise. Open Engineering [online]. 2020, 10(1), p. 129-139. eISSN 2391-5439. Available from: https://doi.org/10.1515/eng-2020-0021

[16] SUBRT, T. Economic and mathematical methods (in Czech). Plzen: Vydavatelstvi a nakladatelstvi Ales Cenek, 2011. ISBN 978-80-7380-345-2.

[17] SIPUS, D., ABRAMOVIC, B. The possibility of using public transport in rural area. Procedia Engineering [online]. 2017, 192, p. 788-793. ISSN 1877-7058. Available from: https://doi.org/10.1016/j.proeng.2017.06.136

[18] ZISKAL, J., HAVLICEK, J. Economic mathematical methods: study texts for distance learning (in Czech). Prague: Credit, 1999. ISBN 80-213-0510-x.

[19] STOPKA, O., BARTUSKA, L., KUBASAKOVA, I. Selecting the most suitable region in the selected country for the placement of the bi-modal freight village using the WSA method. In: 9th International Conference Intelligent Technologies in Logistics and Mechatronics Systems ITELMS 2014: proceedings. 2014. p. 238-243.

[20] MIRCETIC, D., NIKOLICIC, S., MASLARIC, M., RALEVIC, N., DEBELIC, B. Development of S-ARIMA model for forecasting demand in a beverage supply chain. Open Engineering [online]. 2016, 1, p. 407-411. eISSN 2391-5439. Available from: https://doi.org/10.1515/eng-2016-0056

[21] FRIEBELOVA, J. Operational analysis (in Czech). Ceske Budejovice: Faculty of Economics of the University of South Bohemia, 2009. ISBN 978-80-7394-193-2.

[22] ZITRICKY, V., GASPARIK, J., PECENY, L. The methodology of rating quality standards in the regional passenger transport. Transport Problems [online]. 2015, 10, p. 59-72. ISSN 1896-0596, eISSN 2300-861X. Available from: https://doi.org/10.21307/tp-2015-062

[23] Methods of systematic and creative problem solving - European Social Fund Prague \& EU (in Czech) [online] [accessed 2017-02-02] Prague, 2011. Available at: http://kem.vscht.cz/files/uzel/0012237/7.\%20Metody\%20systematick\%C3\%A9ho\%20 \%C5\%99e\%C5\%A1en\%C3\%AD.pdf?redirected

[24] Mapy.cz (in Czech) [online] [accessed 2017-02-02]. 2017. Available at: https://mapy.cz/ zakladni? $\mathrm{x}=14.0970000 \& \mathrm{y}=49.9847980 \& \mathrm{z}=11$

[25] Current price of petrol, price of diesel - Kurzy.cz (in Czech) [online] [accessed 2017-01-02]. 2017. Available at: http://www.kurzy.cz/komodity/benzin-nafta-cena/ 
[26] GHADI, M., TOROK, A. A comparative analysis of black spot identification methods and road accident segmentation methods. Accident Analysis and Prevention [online]. 2019, 128, p. 1-7. ISSN 0001-4575. Available from: https://doi.org/10.1016/j.aap.2019.03.002

[27] CHEN, K.-H., LIAO, C.-N., WU, L.-C. A selection model to logistic centers based on TOPSIS and MCGP methods: the case of airline industry. Journal of Applied Mathematics [online]. 2014, 470128, p. 1-10. ISSN 1110-757X, eISSN 1687-0042. Available from: https://doi.org/10.1155/2014/470128 